\title{
Use of Ultraviolet C (UVC) Radiation to Inactivate Infectious Hematopoietic Necrosis Virus (IHNV) and Viral Hemorrhagic Septicemia Virus (VHSV) in Fish Processing Plant Effluent
}

\author{
Luis OB Afonso ${ }^{1 *}$, Zina Richmond ${ }^{1}$, Alexandra A Eaves ${ }^{1}$, Jon Richard², Laura M Hawley² and Kyle A Garver ${ }^{2}$ \\ ${ }^{1}$ British Columbia Centre for Aquatic Health Sciences, 871A Island Hwy, Campbell River, BC, V9W 2C2, Canada \\ ${ }^{2}$ Pacific Biological Station, Department of Fisheries and Oceans, 3190 Hammond Bay Rd, Nanaimo, BC, V9T 6N7, Canada
}

\begin{abstract}
We determined the stability of infectious hematopoietic necrosis virus (IHNV) and viral hemorrhagic septicemia virus (VHSV) suspended in either fish processing plant effluent blood water (EBW) or culture media and examined the effectiveness of UVC radiation to inactivate IHNV and VHSV suspended in both solutions. Without exposure to UVC, IHNV and VHSV were maintained in $4^{\circ} \mathrm{C}$ blood water for up to 48 hours without significant reduction in virus titer. However when exposed to UVC radiation using a low pressure mercury vapour lamp collimated beam, IHNV and VHSV were inactivated, and the efficacy of UVC radiation was dependent upon the solution and virus type being treated. A 3-log reduction for VHSV and IHNV in culture media was achieved at 3.28 and $3.84 \mathrm{~mJ} \mathrm{~cm}^{-2}$, respectively. The UV dose needed for a 3-log reduction of VHSV in EBW was $3.82 \mathrm{~mJ} \mathrm{~cm}^{-2}$. However, exposure of IHNV in EBW to the maximum UVC dose tested $\left(4.0 \mathrm{~mJ} \mathrm{~cm}^{-2}\right)$ only led to a 2.26 -log-reduction. Factors such as particle size, and possible association of viruses with suspended EBW particulate, were not investigated in this study, but may have contributed to the difference in UVC effectiveness. Future work should emphasize improved filtration methods prior to UV treatment of processing plant EBW at an industrial scale.
\end{abstract}

Keywords: IHNV; VHSV; UVC; Log reduction; Blood water effluent; Fish processing plant

\section{Introduction}

Viral and bacterial diseases can affect wild and farmed aquatic animals. In the aquatic environment these infectious agents can spread through the water and infect both commercially harvested and farmreared fish and shellfish [1]. Disease control in wild and farmed aquatic animals is a complex issue, as the dissemination of infectious diseases in either fresh or salt water can be facilitated by natural current and tidal exchanges as well as through anthropogenic practices such as recreational and commercial boat activities. Additionally, infectious diseases can potentially be introduced from alternate sources such as fish/shellfish processing plants [2]. Consequently, biosecurity measures are among the most effective means to prevent the spread of infectious diseases in the aquatic environment. To mitigate the risk of pathogen dispersion through effluent discharges, alternative disinfection and pathogen neutralization procedures are being investigated.

Current technology used for effluent blood water (EBW) disinfection at fish processing plants is largely dependent on mechanical and/or chemical processes. Processing plants screen effluent for particles larger than $0.5 \mathrm{~mm}$, which are collected and transported off site. However, the remaining EBW, which is high in organics, is generally released into the marine environment for natural dilution to take place [2]. Some fish processors disinfect EBW with chlorine prior to discharging it into the environment; however, organic material is known to inactivate chlorine to varying degrees [3], and many of the plants can not separate organic material from the wastewater or ensure complete mixing of the chlorine and wastewater. Additionally, the higher $\mathrm{pH}$ levels of seawater ( $\mathrm{pH} 8$ ) compared to freshwater ( $\mathrm{pH} 6.5$ to 7.0 ) changes the active form of chlorine from hypochlorous acid to hypochlorite which is 100 times less effective as a disinfectant [4] than hypochlorous acid. Therefore, adequate chlorination levels are often not reached and if so are difficult to maintain. Moreover, this type of treatment is labor intensive and leaves room for miscalculation and contamination of the environment with a toxic substance.
An alternative technology for EBW disinfection is Ultraviolet (UV) irradiation. UV irradiation causes inactivation of microorganisms [5] by its effects on DNA and RNA [6]. The UV irradiation is emitted in the UVA, UVB and UVC bands, which are differentiated by the range of wavelength (nanometers). The UVC band emits radiation in a wavelength ranging from 280 to $200 \mathrm{~nm}$, and presents the most germicidal effects [7]. Several studies have examined a variety of microorganisms' response to UV radiation, and results demonstrated that UV may lead to microorganims' inactivation in a time- and dosedependent manner [7-15].

Although there is no regulatory requirement in North America for treating fish/shellfish processing plant EBW, it is necessary to understand if pathogens remain viable in the EBW, and if so, what disinfectant technologies prove efficacious against potential pathogens. Among the infectious pathogens that are important to monitor for in processing plant EBW are viral agents such as infectious hematopoietic necrosis virus (IHNV) and viral hemorrhagic septicemia virus (VHSV). IHNV and VHSV are among two of the three aquatic rhabdoviruses listed by the OIE (the World Organization for Animal Health). Both virus are widespread throughout the Northern Hemisphere and have caused severe mortality events in cultured and wild fish populations.

*Corresponding author: Luis OB Afonso, British Columbia Centre for Aquatic Health Sciences, 871A Island Hwy, Campbell River, BC, V9W 2C2, Canada, E-mail: luis.afonso@cahs-bc.ca

Received December 20, 2011; Accepted January 15, 2012; Published January 21,2012

Citation: Afonso LO, Richmond Z, Eaves AA, Richard J, Hawley LM, et al. (2012) Use of Ultraviolet C (UVC) Radiation to Inactivate Infectious Hematopoietic Necrosis Virus (IHNV) and Viral Hemorrhagic Septicemia Virus (VHSV) in Fish Processing Plant Effluent. J Aquac Res Development 3:120 doi:10.4172/21559546.1000120

Copyright: (c) 2012 Afonso LO, et al. This is an open-access article distributed under the terms of the Creative Commons Attribution License, which permits unrestricted use, distribution, and reproduction in any medium, provided the original author and source are credited. 
Citation: Afonso LO, Richmond Z, Eaves AA, Richard J, Hawley LM, et al. (2012) Use of Ultraviolet C (UVC) Radiation to Inactivate Infectious Hematopoietic Necrosis Virus (IHNV) and Viral Hemorrhagic Septicemia Virus (VHSV) in Fish Processing Plant Effluent. J Aquac Res Development 3:120 doi:10.4172/2155-9546.1000120

IHNV is the causative agent of infectious hematopoietic necrosis (IHN) that was first described in sockeye salmon in the 1950s at a hatchery in the Pacific Northwest of USA [16]. Since this initial description the virus has not only been detected in all five species of Pacific salmon but also in rainbow trout/steelhead, Atlantic salmon, and several non-salmonid species [17]. Dependent upon fish species, age, density, water temperature, and virus type, losses during acute IHN outbreaks can reach 95\% [18] consequently resulting in devastating economic losses particularly within farmed fish populations. For instance, IHNV epizootics within the Atlantic salmon farming industry in British Columbia, Canada resulted in the estimated loss of $\$ 40$ million in inventory representing \$200 million in lost sales (Odd Grydeland, personal communication).

VHSV, the causative agent of viral hemorrhagic septicemia is considered the most serious disease of farmed rainbow trout in Europe [19]. First described in the early 1930's, VHSV has been detected in an extremely diverse range of fish species in both fresh and seawater environments. Mass mortality events in farmed and wild fish populations have been attributed to this virus and VHS been one of the leading diseases speculated for the collapse and failed recovery of the Pacific herring population in Prince William Sound, Alaska [20-22].

Due to the health threat these viruses pose to cultured and wild fish stocks throughout the Northern Hemisphere, surveillance and control programs are typically undertaken to limit viral distribution. A key component to successful viral disease management programs is in the identification and elimination of potential viral sources. To this end, the objective of this study was twofold: 1) to determine the potential of processing plant effluent to harbour virus by investigating the duration of viability of infectious hematopoietic necrosis virus (IHNV) and viral hemorrhagic septicemia virus (VHSV) in processing plant effluent, and 2) to determine the efficacy of UVC irradiation on the inactivation of IHNV and VHSV in effluent water from a fish processing plant.

\section{Materials and Methods}

\section{Virus amplification and quantification}

Infectious hematopoietic necrosis virus and viral hemorrhagic septicaemia virus VHSV isolates 93-057 and 99-292, respectively were propagated in Epithelioma Papulosum Cyprini (EPC) cells at $15^{\circ} \mathrm{C}$. EPC cells were maintained at $20^{\circ} \mathrm{C}$ using MEM-10 media (minimal essential medium supplemented with $10 \%$ fetal calf serum , $200 \mathrm{mM}$ Glutamax-1, and $5 \mathrm{~mL}$ Sodium Bicarbonate $(7.5 \% \mathrm{w} / \mathrm{v})$. For propagation of virus, media was removed from stock EPC cells and the flasks were inoculated with virus $(0.001 \mathrm{MOI})$. The flasks were incubated at $15^{\circ} \mathrm{C}$ for $45-60$ minutes. Media was then replaced and the flasks were incubated at $15^{\circ} \mathrm{C}$.

Cells were monitored every other day for cytopathic effects (CPE) and virus was harvested after complete destruction of the EPC monolayer. Media, cellular debris and virus particles were pooled from the EPC flasks and transferred into $50 \mathrm{~mL}$ centrifuge tubes. The suspension was centrifuged at $2500 \mathrm{~g}$ for 15 minutes at $4^{\circ} \mathrm{C}$ after which supernatant was aliquoted into cryotubes and stored at $-80^{\circ} \mathrm{C}$ until use. Virus stock titer was determined using plaque assay as described previously [23].

\section{Virus stability in blood water and culture media}

Processing plant effluent blood water (EBW) used in these studies was generated during the processing of farmed Atlantic salmon (Salmon salar). The processing water is a mixture of UV filtered seawater (95\%) and fresh water (5\%), and the average temperature, $\mathrm{pH}$ and salinity of the EBW was $10^{\circ} \mathrm{C}, 7.16$, and $21 \mathrm{ppt}$, respectively. The EBW was collected after drum filtration (retains particle sizes $>500$ microns) in $5 \mathrm{~L}$ plastic containers and transported refrigerated $\left(4^{\circ} \mathrm{C}\right)$ to the BC Centre for Aquatic Health Sciences (Campbell River, BC) and subsequently held overnight at $4^{\circ} \mathrm{C}$.

The following day, $40 \mathrm{~mL}$ EBW sub-samples were transferred into six, $50 \mathrm{~mL}$ tubes and inoculated with IHNV (93-057), VHSV (99-292) or HBSS+ab (negative controls). Stock virus samples were thawed and added to the blood-water samples to achieve a titre of approximately $1 \times 10^{6} \mathrm{pfu}$ 's $/ \mathrm{mL}$. Sample tubes were mixed by inversion and incubated at $4^{\circ} \mathrm{C}$ and $15^{\circ} \mathrm{C}$. Tubes were immediately sampled (T-0) by removing a 2 $\mathrm{mL}$ aliquot which was subsequently filtered $(0.45 \mu \mathrm{m})$, serially diluted and plated onto EPC cells. Plates were incubated for 1 hour and then an overlay of MEM-4-HEPES+Ab was added. Additional sampling was performed at 30 minutes, 3 hours, 6 hours, 24 hours, 48 hours and 7 days post virus seeding of the EBW. Cell culture plates showing CPE (plaque development) were fixed and stained using a crystal violet $(0.25$ g) and buffered formalin $(250 \mathrm{~mL})$ solution.

Similarly, IHNV and VHSV stabilities were determined in culture media (MEM). Media, aliquoted in $15 \mathrm{~mL}$ conical tubes, was seeded with $1 \times 10^{6} \mathrm{pfu} / \mathrm{mL}$ of either IHNV or VHSV and inoculated at $4^{\circ} \mathrm{C}$ Aliquots were removed immediately (T0) as well as at 24,48 , and 72 hours post seeding and virus was quantified using plaque assay as described above.

\section{UVC radiation studies}

The ultraviolet C (UVC - germicidal) studies were carried out using a collimated beam (Trojan Technologies) equipped with a low pressure mercury vapor lamp (GPH460TSL/4, Trojan Technologies) that produces UVC at $254 \mathrm{~nm}$. UV transmittance (UV intensity transmitted through $1 \mathrm{~cm}$ path length of the sample) was determined using a UV spectrophotometer (P245C UV photometer, Trojan technologies). UV intensity at the air-liquid interface was measured using a calibrated radiometer (ILT1700, International Light Technologies).

UVC radiation treatments were applied to two types of solutions: viral culture media (MEM) and fish processing plant EBW. Effluent generated during normal operational loads in a fish processing plant was collected as previously described. Effluent blood water was diluted in distilled water in order to achieve a transmittance of $25 \%$.

Two trials were conducted to determine UV inactivation of IHNV and VHSV when suspended in culture media (trial 1 and 2), while the remaining trial (trial 3) determined the UV inactivation of the two viruses when suspended in EBW. In trials 1 and 2, viruses (IHNV and VHSV) were exposed to 0 and $1.5 \mathrm{~mJ} \mathrm{~cm}^{-2}$ and $0,1.0,1.5,2.0,2.5,4.0,10$

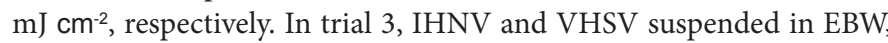
were subjected to UVC doses of: $1.0,1.5,2.0,2.5$, and $4.0 \mathrm{~mJ} \mathrm{~cm}{ }^{-2}$. In all studies approximately $1 \times 10^{6} \mathrm{pfu}$ of viruses $/ \mathrm{mL}$ was added to $25 \mathrm{~mL}$ of fish processing plant effluent or culture media. Samples $(25 \mathrm{~mL})$ were irradiated in $60 \mathrm{~mm}$ x $36 \mathrm{~mm}$ sterile Petri dishes. Five minutes prior to and during UV exposure, samples were continuously stirred on a magnetic stir plate at room temperature. The same stir speed was applied to all treatments and all UV exposure trials were carried out using the same batch of effluent blood water or media.

\section{Evaluation of UVC radiation treatments}

The efficacy of the UVC sterilization treatments were evaluated by comparing quantities of infectious virus pre and post UVC treatments. 
Citation: Afonso LO, Richmond Z, Eaves AA, Richard J, Hawley LM, et al. (2012) Use of Ultraviolet C (UVC) Radiation to Inactivate Infectious Hematopoietic Necrosis Virus (IHNV) and Viral Hemorrhagic Septicemia Virus (VHSV) in Fish Processing Plant Effluent. J Aquac Res Development 3:120 doi:10.4172/2155-9546.1000120

Page 3 of 5

Infectious virus was quantified using the plaque assay [23]. The dose response curves of the effects of UVC irradiation on IHNV and VHSV infectivity are presented as $\log 10$-reduction values, which were calculated relative to dose zero. The log-reduction data was subjected to the least-square linear model using Sigma-Stat (Systat Software Inc, Chicago IL), and data was checked for normality (Shapiro-Wilk) and constant variance (Systat Software Inc, Chicago IL). Log-reduction values obtained from replicate well counts are presented in the graphs. The stability curve data is also presented as $\log 10$ values (mean \pm SEM) obtained from replicate well counts and ANOVA (Systat Software Inc) was performed to determine differences in viruses' titration during 3 days.
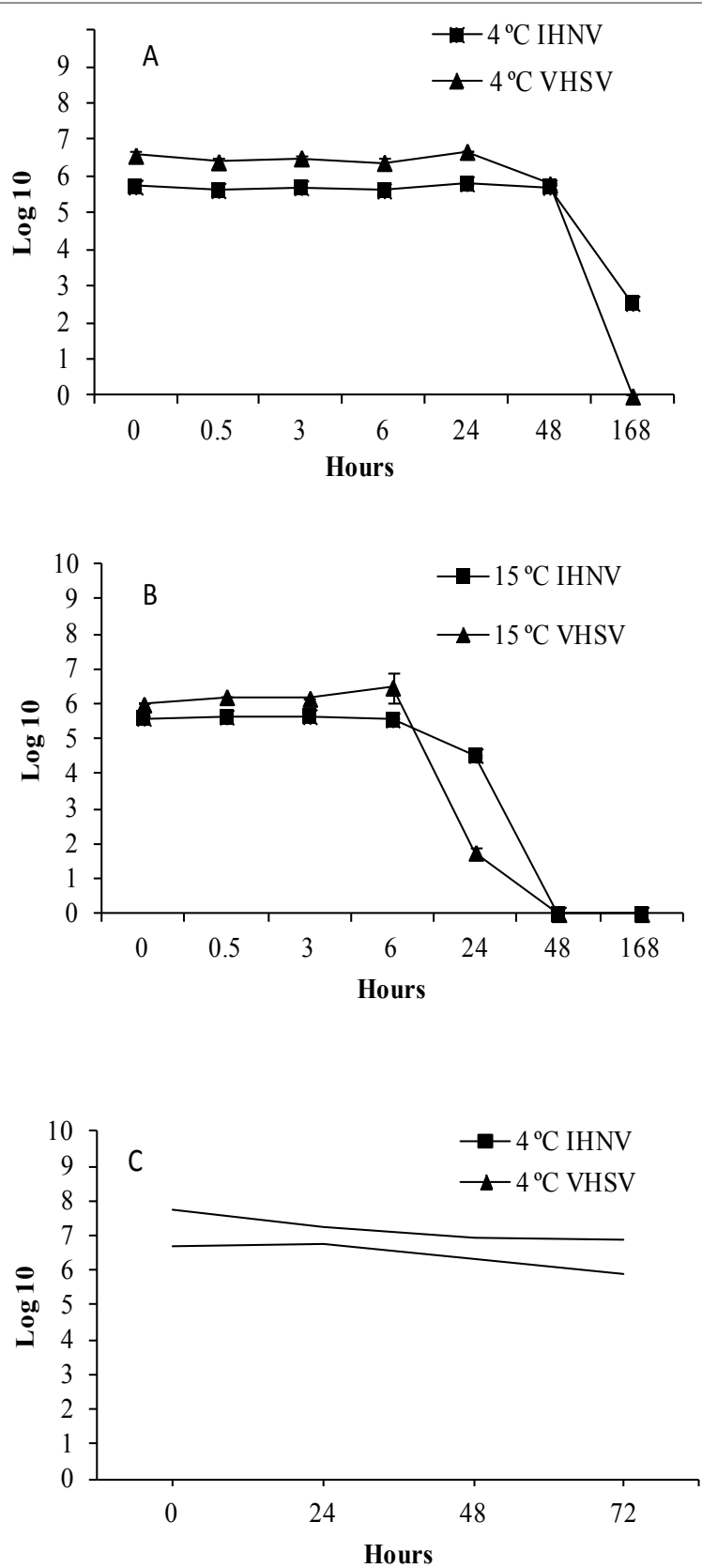

Figure 1: Stability curve of IHNV and VHSV $(\log 10)$ suspended in fish processing plant effluent at (A) $4^{\circ} \mathrm{C},(B) 15^{\circ} \mathrm{C}$ and (C) in culture media at $4{ }^{\circ} \mathrm{C}$
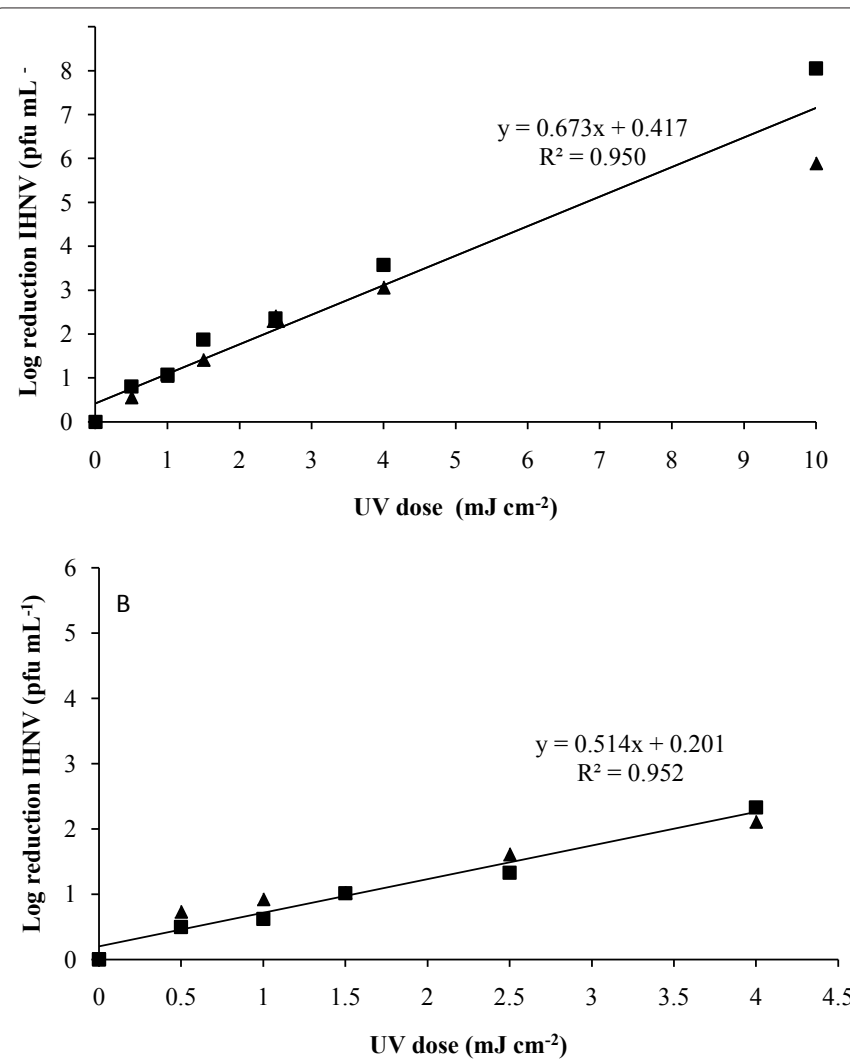

Figure 2: Dose-response curve of IHNV suspended in culture media $(A)$ and fish processing effluent (B). Replicate plate well counts are shown (areplicate $1 ; \boldsymbol{\Delta}$ replicate 2 ).

\section{Results}

Virus stability in processing plant effluent versus culture media

IHNV and VHSV were less stable (more rapidly inactivated) when suspended in $15^{\circ} \mathrm{C}$ effluent blood water than when suspended in either culture media or EBW at $4^{\circ} \mathrm{C}$ (compare Figures $1 \mathrm{~A}, \mathrm{~B}$ and C). At 48 hours post inoculation, no IHNV or VHSV was detected in $15^{\circ} \mathrm{C}$ blood water despite being seeded at $4 \times 10^{5} \mathrm{PFU} / \mathrm{mL}$ and $1 \times 10^{6} \mathrm{PFU} / \mathrm{mL}$, respectively (Figure 1B). Conversely, viral titres for IHNV and VHSV suspended in EBW or culture media or at $4^{\circ} \mathrm{C}$ remained fairly consistent out to 48 hour post inoculation (Figures $1 \mathrm{~A} \& \mathrm{C}$ ). In comparing the stabilities of VHSV and IHNV in EBW, it was revealed that VHSV was inactivated faster than IHNV at both $4^{\circ} \mathrm{C}$ and $15^{\circ} \mathrm{C}$ (Figures $1 \mathrm{~A} \mathrm{\&} \mathrm{B}$ ). Viral titres for IHNV suspended in EBW at $4^{\circ} \mathrm{C}$ remained unchanged up to 48 hours post inoculation while VHSV titers were reduced by one $\log$ (Figure 1A).

\section{UVC inactivation of IHNV and VHSV}

Trial 1, in which IHNV and VHSV suspended in culture media were subjected to UVC irradiation at a dose of $1.5 \mathrm{~mJ} \mathrm{~cm}^{-2}$ resulted in a 1.72 and $2.05 \log$ reduction in IHNV and VHSV, respectively (data not shown). In trial 2, exposure of IHNV and VHSV in culture media to UVC at a dose of $1.5 \mathrm{~mJ} \mathrm{~cm}^{-2}$ led to a 1.43 and $1.83 \log$ reduction, respectively (Figures $2 \mathrm{~A}$ and $3 \mathrm{~A}$ ).

The results in Figure 2A showed that the UV dose needed for a 3-log reduction of IHNV suspended in culture media was $3.84 \mathrm{~mJ} \mathrm{~cm}^{-2}$. 

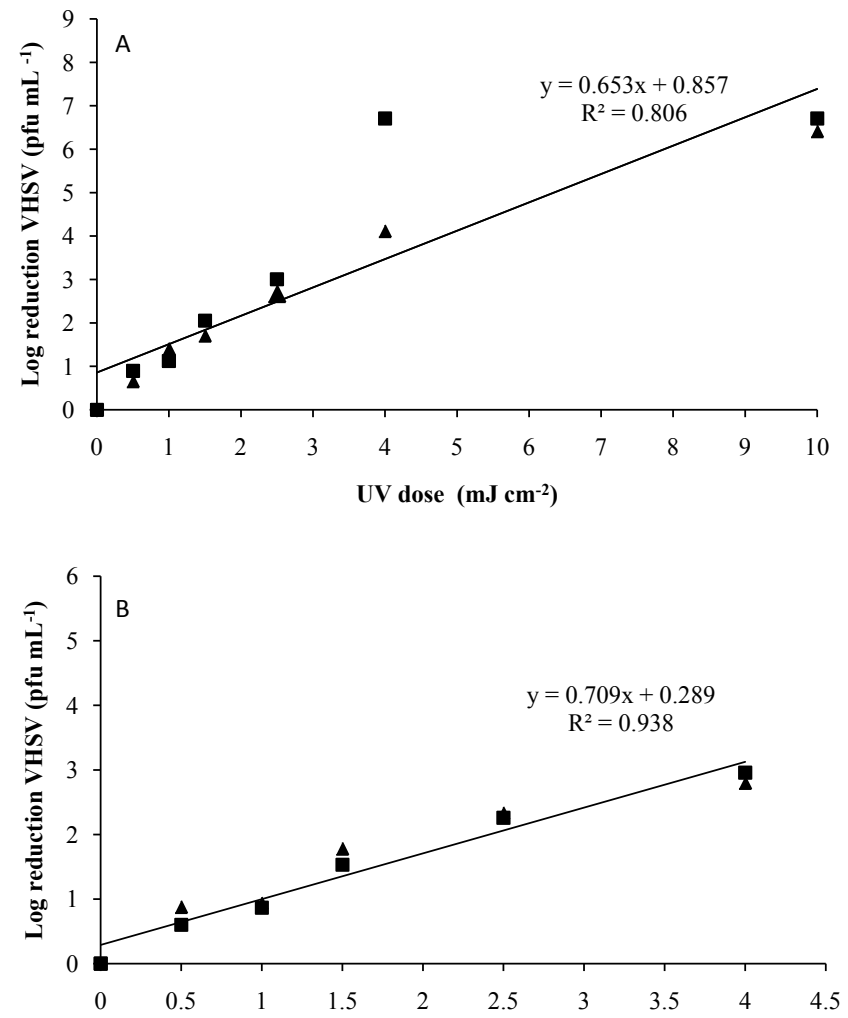

Figure 3: Dose-response curve of VHSV suspended in culture media (A) and fish processing effluent $(B)$. Replicate plate well counts are shown (. replicate $1 ; \boldsymbol{\Delta}$ replicate 2 ).

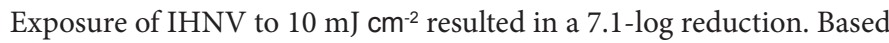
on the least squares linear regression model equation, a UV dose of 8.29 $\mathrm{mJ} \mathrm{cm}{ }^{-2}$ is required for 6-log reduction. For IHNV suspended in EBW, a 2.26-log reduction was obtained at $\mathrm{UV}$ dose of $4 \mathrm{~mJ} \mathrm{~cm}^{-2}$ (Figure 2B).

The UV dose needed for a 3-log reduction of VHSV suspended in culture media (Figure $3 \mathrm{~A}$ ) was $3.28 \mathrm{~mJ} \mathrm{~cm}^{-2}$. Exposure of VHSV to $10 \mathrm{~mJ} \mathrm{~cm}{ }^{-2}$ resulted in a 7.4-log reduction. Based on the least squares linear regression model equation, $\mathrm{UV}$ dose of $7.87 \mathrm{~mJ} \mathrm{~cm}^{-2}$ is required for a 6-log reduction. For VHSV suspended in EBW, a log reduction of 3.12 was obtained at UV dose of $4 \mathrm{~mJ} \mathrm{~cm}^{-2}$ (Figure 3B). The UV dose required for a $3-\log$ reduction is $3.82 \mathrm{~mJ} \mathrm{~cm}^{-2}$.

\section{Discussion}

In this study we determined the stability of IHNV and VHSV in effluent from a fish processing plant as well as the effectiveness of UVC irradiation in sterilizing such wastewater. The aquatic rhabdoviruses, IHNV and VHSV, although exhibited reduced viability in fish processing effluent in comparison to the control media, did persist in blood water (either at 4 or $15^{\circ} \mathrm{C}$ ) for a period of six hours without significant reduction in titers. Viable virus was also found at longer time points post inoculation, however; titers did begin to decline with the rate being dependent upon temperature and species of virus. Due to the ability of IHNV and VHSV to persist in fish/shellfish processing plant effluent for several hours and the fact that wastewater is discharged quickly from plants, there is a risk that infectious viruses could be transferred into open environments via untreated effluent releases when infected fish are being processed.
Using laboratory scale low pressure UV collimated beam, we examined the effectiveness of UVC irradiation for inactivating IHNV and VHSV in fish processing plant effluent blood water (EBW). It is noteworthy that for both IHNV and VHSV, a 1.46 and 1.16 fold lower UV dose, respectively was required in culture media versus blood water to achieve equivalent virus inactivation. Thus, the effectiveness of UVC irradiation was greater in culture median than in effluent blood water from fish processing plants. These results concur with other studies that investigated viral and bacterial reduction in UV treatment systems applied to different types of effluents [7,11]. It is possible that the higher UVC doses required in blood water to achieve equivalent inactivation values for VHSV and IHNV suspended in culture media is due to the presence of particulate matter which affects the transmittance of UVC rays in the solution [24]. Among other particulate matter, processing plant EBW can contain varying levels of soluble proteins, fats, oils, and bacteria [2]. It has been documented that particulate matter in effluents can cause a shielding effect, which protects organisms against the UV radiation [25]. Additionally, UV radiation effectiveness has been shown to be dependent upon the type of particular matter (chemical or biological) [26]. Particulate material can also facilitate virus transfer It has been reported [27] that IHNV can adhere to different particulate material which subsequently can serve as a source of virus infection. These authors also showed that the adsorption rate of IHNV to different suspended solids was not affected by the solution's $\mathrm{pH}$ (acid, neutral, and alkaline). Thus, to maximize UVC effectiveness in disinfecting fish/shellfish processing plant effluent, steps should be taken to further remove particulate materials prior to UV treatment.

In addition to utilizing different UVC doses for the solution being treated (i.e. wastewater vs. culture media) it was observed that UVC dose requirements may vary dependent upon the virus type being treated against. Regardless of whether VHSV was suspended in culture media or effluent blood water, a lower UVC dose was required to obtain equivalent inactivation levels as those observed for IHNV. For instance, a UVC dose of $3.28 \mathrm{~mJ} \mathrm{~cm}^{-2}$ was required for a 3-log10 reduction of VHSV when suspended in culture media as compared to $3.84 \mathrm{~mJ} \mathrm{~cm}^{-2}$ for an equivalent reduction of IHNV in culture media. Differing UVC sensitivities have been observed between infectious pancreatic necrosis virus (IPNV), infectious salmon anemia virus (ISAV), and VHSV with both IPNV and ISAV exhibiting higher tolerance to UVC than VHS virus. When suspended in freshwater, VHSV, ISAV, and IPNV presented a 3-log reduction a UV dose of 3.3, 7.9 and $11.88 \mathrm{~mJ} \mathrm{~cm}^{-2}$, respectively [7]. It has been suggested that size and type of virus acid nucleic genome could affect UV resistance, where single-stranded nucleic acids viruses (such as VHSV and IHNV) are less resistant to UV radiation than double-stranded nucleic acids [7]. Due to similarity of IHNV and VHSV, the genome type and size may not be the only factors influencing viruses' resistance to UV radiation. A recent study that has examined the effects of UVC radiation in RNA (Polivirus 1, Cosakievirus B4, and bacteriophage MS2 - all single stranded linear RNA) and DNA (Adenovirus, Myoviridae, Siphoviridae, etc - all double stranded linear DNA) viruses have shown that the size and type of virus or its nucleic acid genomes could not be used to predict UV radiation effectiveness [13]. The authors suggested that the sensitivity of viruses to UVC treatments may be related to chemical and physical differences in the virion.

Although it is difficult to compare UVC doses across studies due to differences in methodologies, our UVC inactivation rates reported herein corroborate with those reported by Øye and Rimstad [7]. In our study, the UVC dose needed for a 3-log reduction of VHSV suspended in culture media was 3.28 while Øye and Rimstad [7] observed that 
Citation: Afonso LO, Richmond Z, Eaves AA, Richard J, Hawley LM, et al. (2012) Use of Ultraviolet C (UVC) Radiation to Inactivate Infectious Hematopoietic Necrosis Virus (IHNV) and Viral Hemorrhagic Septicemia Virus (VHSV) in Fish Processing Plant Effluent. J Aquac Res Development 3:120 doi:10.4172/2155-9546.1000120

Page 5 of 5

$3.30 \mathrm{~mJ} \mathrm{~cm} \mathrm{~cm}^{-2}$ was necessary for a 3-log reduction of VHSV suspended in freshwater. On the other hand, VHSV suspended in phosphate buffer saline (PBS) with coffee $(0.4 \% \mathrm{v} / \mathrm{v})$ required only $1.84 \mathrm{~mJ} \mathrm{~cm} \mathrm{~cm}^{-2}$ to achieve a 3-log reduction [14]. Differences in UVC inactivation rates between studies demonstrate the importance of having standardized methodologies to test the effectiveness of UVC treatments for viruses in different suspension solutions.

In summary, we demonstrated that both IHNV and VHSV are stable in EBW, but their survivability is affected by both time and temperature. In addition, the results revealed that VHSV seems to be less resilient than IHNV when suspended in EBW. Both viruses were also sensitive to UVC treatment, but the efficiency of the UVC treatment was more pronounced in culture media than in the EBW. Factors such as particle size, and possible association of viruses with EBW particulate, were not investigated in this study, may have contributed to the difference in UVC effectiveness. Although the UVC system showed potential to inactivate viral microorganisms at laboratory scale experiments, it will be important to demonstrate whether a commercial scale UVC system would be efficient for total microorganisms' inactivation. Thus, not only dose (energy required to inactivate microorganisms) but also the inclusion of improved filtration systems prior to UVC treatments requires further investigation.

\section{Acknowledgement}

We wish to thank Jeff Forbes (Co-op student from UVic at BC CAHS), Debbie Collins (BC CAHS), Elan Downey (BC CAHS), and Housyn Mahmoud (Trojan Technologies) for their critical support during field sampling and laboratory analysis. Funds for these studies were provided by the Aquaculture Innovation and Market Access Program (AIMAP-DFO-Canada), Aquaculture Collaborative Research and Development Program (ACRDP-DFO-Canada), and the British Columbia Aquatic food Resources Society (BCAFRS - funds for LOBA).

\section{References}

1. Munn CB (2006) Viruses as pathogens of marine organisms - from bacteria to whales. J Mar Biol Assoc UK 86: 453-467.

2. Islam MS, Khan S, Tanaka M (2004) Waste loading in shrimp and fish processing effluents: potential source of hazards to the coastal and nearshore environments. Mar Pollut Bull 49: 103-110.

3. Torgersen Y, Hastein T (1995) Disinfection in aquaculture. Rev Sci Tech 14: 419-434.

4. Washburn \& Gillis Associates Ltd (1998) Guidelines for disinfection hygiene standards for aquaculture marine grow-out operations and associated services specific to infectious salmon anaemia. Final Report prepared for New Brunswick Department of Fisheries \& Aquaculture, 16 April, 1998.

5. Kurth J, Waldmann R, Heith J, Mausbach K, Burian R (1999) Efficient inactivation of viruses and mycoplasma in animal sera using UVC irradiation. Dev Biol Stand 99: 111-118

6. Cadet J, Anselmino C, Douki T, Voituriez L (1992) New trends in photobiology: Photochemistry of nucleic acids in cells. J Photochem Photobiol B Biol 15: 277 298

7. Øye AK, Rimstad E (2001) Inactivation of infectious salmon anaemia virus, viral haemorrhagic septicaemia virus and infectious pancreatic necrosis virus in water using UVC irradiation. Dis Aquat Organ 48: 1-5.

8. Sako H, Sorimachi M (1985) Susceptibility of fish pathogenic viruses, bacteria and fungus to ultraviolet irradiation and the disinfectant effect of UV-ozone water sterilizer on the pathogens in water. Bull Natl Res Inst Aquaculture 8: 51-58.

9. Hedrick RP, McDowell TS, Marty GD, Mukkatira K, Antonio DB, et al. (2000) Ultraviolet irradiation inactivates the waterborne infective stages of Myxobolus cerebralis: a treatment for hatchery water supplies. Dis Aquat Org 42: 53-59.

10. Hedrick RP, Petri B, McDowell ST, Mukkatira K, Sealey LJ (2007) Evaluation of a range of doses of ultraviolet irradiation to inactivate waterborne actinospore stages of Myxobolus cerebralis. Dis Aquat Org 74: 113-118.

11. Hill VR, Kantardjieff A, Sobsey MD, Westerman PW (2002) Reduction of enteric microbes in flushed swine wastewater treated by a biological aerated filter and UV irradiation. Water Environ Res 74: 91-99.

12. Jacangelo JG, Loughran P, Petrik B, Simpson D, Mcllroy C (2003) Removal of enteric viruses and selected microbial indicators by UV irradiation of secondary effluent. Water Sci Technol 47: 193-198.

13. Shin G-A, Linden KG, Sobsey MD (2005) Low pressure ultraviolet inactivation of pathogenic enteric viruses and bacteriophages. J Environ Eng Sci 4: S7-S11.

14. Huber P, Petri B, Allen S, Lumsden JS (2010) Viral haemorrhagic septicaemia virus IVb inactivation by ultraviolet light, and storage viability at 4 and $20^{\circ} \mathrm{C}$. J Fish Dis 33: $377-380$

15. Bowker C, Sain A, Shatalov M, Ducoste J (2011) Microbial UV fluenceresponse assessment using a novel UV-LED collimated beam system. Water Res 45: 2011-2019.

16. Rucker RR, Whipple WJ, Parvin JR, Evans CA (1953) A contagious disease of salmon possibly of virus orgin. US Fish Wildl Serv Fish Bull 54: 35-46.

17. Bootland LM, Leaong JC (1999) Infectious Haemoatopoietic necrosis virus. In Fish Diseases and Disorders. Volume 3: Viral, Bacterial and Fungal Infections. CABI Publishing; Wallingford, UK.

18. LaPatra SE (1998) Factors affecting pathogenicity of infectious hematopoietic necrosis virus (IHNV) for salmonid fish. J Aquat Anim Health 10: 121-131.

19. Wolf K (1988) The Viruses and Viral Diseases of Fish. Cornell University Press Ithaca, NY, USA.

20. Marty GD, Freiberg EF, Meyers TR, Wilcock J, Farver TB, et al. (1998) Vira haemorrhagic septicaemia virus, Ichthyophonus hoferi, and other causes of morbidity in Pacific herring Clupea pallasi spawning in Prince William Sound Alaska, USA. Dis Aquat Org 32: 15-40.

21. Marty GD, Quinn TJ II, Carpenter G, Meyers TR, Willits NH (2003) Role of disease in abundance of a Pacific herring (Clupea pallasi) population. Can J Fish Aquat Sci 60: 1258-1265.

22. Marty GD, Hulson PJ, Miller SE, Quinn TJ II, Moffitt ST, et al. (2010) Failure of population recovery in relation to disease in Pacific herring. Dis Aquat Org 90: 1-14.

23. Burke JA, Mulcahy D (1980) Plaquing procedure for infectious hematopoietic necrosis virus. Appl Environ Microbiol 39: 872-876.

24. Schoenen D, Zemke V, Kolch A (1991) Effect of the reflection of the UV rays in the disinfection of drinking water. Zentralbl Hyg Umweltmed 191: 396-405.

25. Jolis D, Lam C, Pitt P (2001) Particle Effects on Ultraviolet Disinfection of Coliform Bacteria in Recycled Water. Water Environ Res 73: 233-236.

26. Emerick RW, Loge FJ, Thompson D, Darby JL (1999) Factors Influencing Ultraviolet Disinfection Performance Part II: Association of Coliform Bacteria with Wastewater Particles. Water Environ Res 71: 1178-1187.

27. YoshinakaT, Yoshimizu M, Yoshio E (2000) Adsorption and Infectivity of Infectious Hematopoietic Necrosis Virus (IHNV) with Various Solids. J Aquat Anim Health 12: 64-68. 